\title{
Female Teachers' Perspectives of Learner Autonomy in the Saudi Context
}

\author{
Jameelah Asiri \\ The English Language Institute, University of Jeddah, Jeddah, Saudi Arabia \\ Nadia Shukri \\ The English Language Institute, King Abdulaziz University, Jeddah, Saudi Arabia
}

\begin{abstract}
For decades, the term learner autonomy has been the focus of many studies in the field of education and language learning. This study addresses teachers' perspectives of learner autonomy in Saudi Arabia. It examines whether teachers have the knowledge to encourage and foster learner-autonomy. This study also seeks to explore the challenges English language teachers face in the process of implementing learner autonomy into their EFL classrooms. The investigation was conducted using a sample of 50 English language teachers teaching Saudi students at King Abdul-Aziz University. Data was collected using a 20 - item questionnaire. The study was a mixed research method. Collected data was analyzed using descriptive statistics and thematic analysis. The findings revealed that teachers believe that Saudi learners in the current situation are non-autonomous learners', they lack the knowledge and the training to apply it. Findings also revealed that teachers are familiar with the learner- autonomy yet, they stated that they need proper training and professional development to help encourage learner autonomy. It is an attempt to contribute to the literature underlying learner autonomy in the field of language learning in the Saudi context. Also, it suggests further research to help better comprehend the value of teachers' role in the process of autonomous language learning for learners.
\end{abstract}

Index Terms-(LA) Learner-autonomy, Autonomous learning, Saudi context, teachers perspectives

\section{INTRODUCTION}

Language learning and teaching are processes that involve a selective decision of which pedagogical approaches are implemented. This crucial decision has been the topic of investigation in the language learning and teaching field for many decades. Developing a pedagogical approach that enables both teachers and students to achieve progress is an area that has required intensive research. Traditional literature refers to a variety of language teaching methods such as the classical method or know as grammar translation method, the communicative language teaching and others. In the late 1980s however, researchers such as Henri Holec (1979) took on a new approach to language teaching and learning which explored learner autonomy. Holec (1981), the author who examined autonomy in language learning, refers to learner autonomy as the learners' ability to take responsibility for their own learning. (cited here as Holec 1981).

For decades, EFL learners have experienced changes in language teaching methods as theoretical knowledge developed. Despite these changes, however; it remains a challenge to encourage learners to adapt to a concept that shifts the entire focus of learning from the teachers to the students themselves. As a concept, learner autonomy revolves around the idea that students themselves are responsible for their intellectual learning, rather than their teachers. Autonomous learning is based on the notion that learners' abilities develop individually and therefore, they must rely on themselves to achieve the progress they aim to achieve. Researchers such as Little (1995) believed in the positive effect of fostering the notion of autonomy and actively encouraged students to adapt it. Little (1995) asserts that language learners who acknowledge responsibility regarding their learning will probably accomplish their learning targets; and in the event that they accomplish their learning goals, they are more capable to keep an uplifting state of mind in the future. Similarly, other researchers such as Al Asmari (2013), and Borg and Al-Busaidi (2012) agree with Little's (1995) assertions, particularly about the benefits of adopting the concept with EFL learners.

Reviewed literature and most studies (e.g., Camilleri, 1999; Candy, 1991; Al Arabai, 2017) in the field of learnerautonomy focuses on learners and the results of promoting learner autonomy, however, teachers play a key role in promoting the concept and encouraging it. On the other hand, teachers are part of the learning environment that is governed by the cultural traits that may facilitate or prevent learner autonomy (Ho and Crookall, 1995). In Saudi Arabia, EFL environment is slowly developing specially in the field of language education. Therefore, there is a limited number of studies that investigates elements that contributes to the facilitation or the prohibition of learner autonomy. The cultural aspects of the Saudi context suggests that the teacher remains the primary source of language and most importantly represents an authority figure in the EFL classrooms (Ho and Crookall, 1995). Acknowledging the Saudi educational culture, has the educational environment in Saudi Arabia changed? And are the teachers willing to shift the attention to the learners by promoting the concept of autonomous learning? The current situation of learner autonomy in 
Saudi Arabia is not clear due to the limited number of research studies that focuses on teachers' perspectives and contributions to promote the concept of learner autonomy.

\section{A. Statement of the Problem}

Literature in the field of learner-autonomy in the Arab context and specifically in the Saudi context is limited. Therefore, an investigation on the teacher's role in promoting the concept to EFL learners is the focal point of this paper to help understand the significant role teachers play in enhancing and developing the language learning process. The study also sheds light on the difficulties teachers may face while implementing learner autonomy into their teaching practices.

\section{B. Objectives of the Study}

Acknowledging the importance of teachers' roles in promoting learner autonomous, this study aims to:

1) To examine teachers' knowledge of learner autonomy in the current situation.

2) To explore teachers' perspectives of learner autonomy and their implications to promote it in EFL classrooms.

3) To identify the challenges teachers may face in encouraging and fostering learner autonomy.

\section{Research Questions}

1) What is the teachers' knowledge of learner autonomy?

2) What are the factors that may prevent teachers from encouraging and implementing learner autonomy in their classrooms?

\section{LITERATURE REVIEW}

\section{A. What Is Learner Autonomy?}

Researchers have published studies on the topic of autonomous learning (Holec, 1981; Little, 1998; Bensons and Voller, 2014; Smith, 2008; La Ganza, 2008). The defining characteristic of autonomous learning is that learners take responsibility for their own learning. In this process, learners are encouraged to develop independent learning skills and strategies, where they can develop their abilities depending on their effort. Researchers such as Little (1998) have worked to expand the notion of learner autonomy to include language learning. In his book Teaching Modern Languages, Little (1998) explains, in the event that students are to be effective communicators in their target language, they should be autonomous to the degree of having adequate independence and self-confidence. Learners need to fulfill a veriety of social, psychological and discourse parts or roles in which they will be find themselves casted in.

The rise in popularity of autonomy in language learning over the past few years has led to a variety of terms that refer to the same concept (learner autonomy). The most commonly used terms that refer to autonomy in language learning are, self-direction, self-access, distance learning, self-instruction and out of class learning. Holec (1980), widely regarded as the father of autonomous language learning theory, defines autonomous learning as the learner being "capable of taking charge of his own learning" (as cited in Schmenk, 2005, p. 4). Similarly, Smith (2008) describes learner autonomy as learners having the power, ability and right to learn. La Ganza (2008) states that learner autonomy is the result of critical reflectivity and therefore can be commonly defined as the willingness and the capability to manage constraints within a vision of education as liberation and empowerment. Little (2002) provides his own definition, stating that learner autonomy is primarily a psychological assocation to the process of language learning learners' develop, that is known as number of different behaviours. Such as the ability to be more independent, critical reflectivity, making decisions and independent action. In summary, all of these definitions point to the central idea of learner autonomy as the ability learners have or develop to take charge of their own learning. Therefore, for the purposes of this study autonomous learning is defined simply as the learners' ability to take charge of their own learning.

\section{B. Theoretical Basis of Learner Autonomy}

John Piaget, 1971first presented the theory of constructivism 60 years ago. Piaget asserts that knowledge is not a representation of reality. Rather, it is constructed and thus has an adaptive function. In associating autonomous learning with constructivism, Candy (1991) presents a strong argument stating that one of the focal principles of constructivism is that people try to give meaning and offer significance to, or interpret and construct a number of occasions, events and ideas in which they face on a daily basis. In Candy's terms, constructivism leads directly to the notion that knowledge is an innate process and therefore it cannot be taught, but only constructed, as a result knowledge is something that language learners build and construct on. Thus, if learners are able to construct their own learning based on a series of experiences and events, they are then clearly responsible for their own learning.

Constructivism is based on the principle of constructing knowledge individually without the aid of a more knowledgeable 'other,' in this case, an instructor. Using constructivism as a framework allows us to look at knowledge as something that can be constructed using a variety of resources, such as experiences or information gathered from books or the Internet. Thus, while the sources of knowledge may differ, the concept of forming it and developing autonomously is what is most significant.

\section{Learner Autonomy -Teaching Strategies}


Before considering the implementation of learner autonomy into their teaching, teachers need to consider a number of elements. Teacher autonomy is the starting point for a successful implementation of learner autonomy teaching strategies. This term refers to teachers believing in the concept and being autonomous learners themselves (Little, 1995). Teachers can implement and promote LA with learner autonomy strategies, which are all dedicated to train EFL learners to take more responsibility for their own learning. This encouragement starts with understanding the learners' needs and objectives of the target language. First, teachers need to guide learners towards deciding on their objectives and needs. Second, teachers need to consider aligning the institution framework and objectives and with EFL learners needs and guide them accordingly. Third, intensive focus on communicative tasks is highly important (Benson, 2013). Fourth, reviewing and monitoring individual progress and helping the learners evaluate their own progress helps in promoting autonomous learning. The teacher should also train learners to take achievement tests using other resources such as online assessment. Finally, the teacher can also foster learner autonomy through assigning learners to complete autonomy projects, where it allows students to engage in situations that require them to use the target language for the purpose of communication (Little, 1995).

\section{Challenges Teachers Face in Implementing Learner-autonomy}

When discussing learner autonomy in language learning classrooms, it's important to note that not all researchers agree on the effectiveness of self-instruction (Al-Shaqsi, 2009; Camilleri, 1999; Burkert \& Schwienhorst, 2008). On the other hand, Little (2000) pointed out the lack of research in the area of learner autonomy stating that "very few instructions are solidly based on research results or the results are inconclusive" (p.23). As a result, some teachers may not believe in the concept and therefore may not be willing to support initiatives to implement autonomous learning practices in their classrooms. For example, Burkert and Schwienhorst (2008) provide evidence that teachers who are not autonomous learners themselves language learners could have an adverse influence on the advancement of autonomy in their students. In a research study conducted in Thailand, Reinders (2014) explains the difficulties he faced while attempting to encourage autonomous learning among his Thai students. He confirms a number of factors that leads to these challenges, such as learners' limited exposure to English language, because it is taught as a foreign language. Therefore, students were only exposed to the second language two hours a week and did not use it outside the classroom. This contributed to the lack of desire to engage in autonomous learning activities outside the classroom.

Another difficulty in adapting autonomous learning practices in Thailand was reported by Kongchan and Darasawang (2015). In their book, Innovation in language learning and teaching, they reported that teachers and staff were not dedicated (full-time) enough to manage and run the self-accessing Centers (SACs) created to foster individual learning. Thus, most teachers have time issues when they attempt to implicate or encourage their students to adopt learner-autonomy. To address these challenges, the authors refer to another more successful case where the SACs did not face problems. In this case, also in Thailand, the center had its own staff (part-timers working only in the center), and the teachers of the school were also encouraged to work in the center. In addition, they also hired a part-time staff. This example points to the fact that although autonomous learning projects may face challenges, these challenges can be adequately addressed.

Similarly, a study conducted by Dang (2010) at La Trobe University in Vietnam noted that popular educational practices in Vietnam were associated with retaining and remembering as opposed to testing, experimenting and creating learning. Despite significant investment and effort to improve autonomous learning practices and change the perspectives of learners, teachers and stakeholders; classroom practices and students' learning activities have not changed much.

In Saudi Arabia, encouraging learner autonomy may be challenging. Despite the resources available both inside and outside the classroom, language learners find it difficult to rely on their efforts to learn English. Similar to the case of the Thai learners in Dang's (2010) study, Saudi students, whose native language is Arabic, have limited exposure to L2 and this limited exposure to the L2 often prevents learners from trusting their independent learning abilities. In a study conducted in Jeddah, Saudi Arabia, Khan (2011) reveals, "Saudi students are not exposed to listening or speaking activities in their daily life interaction at home, nor at school, nor in the market or public places. Such conditions dampen the spirit and stunt the growth of pupils" (p.1251). In light of these challenges, this research study attempts to draw a picture on teachers' perception of learner autonomy, which contributes to the success or failure of the implementation of such concept acknowledging the important role they play in the process of language learning. Also, what teachers are doing to encourage their EFL learners to become autonomous learners? In addition to how they apply these practices in their classrooms.

\section{METHODOLOGY}

\section{A. Participants}

The participants of this study were 50 female EFL teachers at the English Language Institute (ELI), King Abdul-Aziz University (KAU) in the city of Jeddah, Saudi Arabia. All participated teachers were teaching English language at different levels in the foundation year program. The taught levels are introductory, beginner, pre-intermediate and intermediate level. Majority of the female participants are experienced language teachers of not less than 5 years. 


\section{B. Research Design}

This research study is purposefully conducted using a descriptive research design that aims to present valuable findings to better understand EFL teachers' knowledge, perceptions and challenges. Also, to present an overview of the current situation of autonomous language learning. Therefore, quantitative and qualitative research methods where used to analyze the data attentively. A quantitative analysis is essential to give accurate numerical data (Hancock, Ockleford, and Windridge 2009). Johnson \& Turner (2003) state that qualitative methods are viewed as a basic supplement to quantitative methods on the grounds that the element that decides a program's success from failure are a long way from transparent. The questionnaire had two parts. The first part contained 18 Likert scale statements to investigate teachers' knowledge and understanding of learner autonomy. The second part had two open ended questions to better comprehend how teachers are fostering and encouraging LA and also, to better understand the difficulties they may face in adopting the concept.

\section{Data Collection Procedures}

\section{Piloting}

The questionnaire survey was piloted with 20 participants prior to the main study to avoid ambiguity. The instrument demonstrated a high content of validity and reliability $(0.743)$.

\section{Main Study}

The teachers' questionnaire survey was adapted from another study carried out in Al-Taif University, Saudi Arabia by Alasmari (2013). The data of this study were collected through sending the questionnaire to the ELI teachers using (google drive). The targeted participants were EFL foundation year teachers. The data of the questionnaire was automatically exported to a MS ${ }^{\circledR}$ Excel file that was later exported to a SPSS ${ }^{\circledR}$ statistical analysis software.

\section{Instrumentation}

The instrument of this study was a survey with a Likert-scale and an open-ended questionnaire. The first part of the questionnaire survey contained 18-items categorized into 3 groups. The 18 Likert-scale statements were analyzed using SPSS $^{\circledR}$. The second part of the questionnaire contained two open-ended questions that were analyzed using thematic analysis.

\section{E. Results}

Teachers' Perceptions and Knowledge of Learner Autonomy

For the first research question, which was: 'what is the teachers' knowledge of learner autonomy?'

The results are presented in table 1, 2, 3 and 4 below.

TABLE 1.

TEACHERS’ RESPONSES TO STATEMENTS RELATED TO LEARNER AUTONOMY- CURRENT SITUATION

\begin{tabular}{llllll}
\multicolumn{7}{c}{ TEACHERS' RESPONSES TO STATEMENTS RELATED TO LEARNER AUTONOMY- CURRENT SITUATION } \\
\hline Statements & $\begin{array}{l}5 \text { Strongly } \\
\text { Agree }\end{array}$ & 4 Agree & $\begin{array}{l}\text { 3 Neither } \\
\text { Or N/A }\end{array}$ & 2 Disagree & $\begin{array}{l}\text { 1 Strongly } \\
\text { Disagree }\end{array}$ \\
\hline 1-Students set up their own learning goals & $12 \%$ & $16 \%$ & $30 \%$ & $26 \%$ & $16 \%$ \\
\hline 2-The students tell the teacher what they would like to learn & $10 \%$ & $26 \%$ & $20 \%$ & $34 \%$ & $10 \%$ \\
\hline $\begin{array}{l}\text { 3-Students feel very concerned to perform well in the } \\
\text { classroom }\end{array}$ & $16 \%$ & $42 \%$ & $26 \%$ & $14 \%$ & $2 \%$ \\
\hline $\begin{array}{l}\text { 4-Student think about their relationship to the rules they have } \\
\text { learned while learning a new grammar rule }\end{array}$ & $14 \%$ & $50 \%$ & $18 \%$ & $16 \%$ & $2 \%$ \\
\hline $\begin{array}{l}\text { 5-Students try to discover knowledge in English on their own } \\
\text { rather than obtaining knowledge from the teacher }\end{array}$ & $2 \%$ & $18 \%$ & $38 \%$ & $36 \%$ & $6 \%$ \\
\hline $\begin{array}{l}\text { 6-Students reflect on test performance and compare it with } \\
\text { other students }\end{array}$ & $8 \%$ & $38 \%$ & $20 \%$ & $24 \%$ & $10 \%$ \\
\hline
\end{tabular}

The results illustrated that $28 \%$ of the teachers believe that EFL learners are able to set up their own goals. Also, a high percentage of $30 \%$ of the teachers found statement 1 does not apply to their current situation with their students and they couldn't decide whether to agree or disagree. The highest percentage of teachers' responses disagreed with the statements with a percentage of $42 \%$. In response to statements 2 , a percentage of $44 \%$ of the teacher disagreed with the fact that their students tell them what they would like to learn. On the other hand, 36\% agreed with the statement and $20 \%$ found the statement not applicable to their situation. In response to statements 3, majority of the teachers with a percentage of $58 \%$, agreed that students felt very concerned to perform well in the classroom. However, a low percentage of $16 \%$ of the teachers disagreed and $26 \%$ found the statement not applicable to their classroom situation.

Results of statement 4 revealed that $64 \%$ of the teachers believe that students think about their relationship to the rules they have learned while learning a new grammar rule. On the other hand, $18 \%$ of the teachers disagreed and also $18 \%$ found that not applicable to their situation with the students. Teachers' responses to statement 5 revealed that $42 \%$ of the teachers disagreed with the statement "students try to discover knowledge in English on their own rather than obtaining knowledge from the teacher. However, a low percentage of $20 \%$ of the teachers agreed with the statement and 38 of the teachers were not able to decide or found the statement not applicable to their situation. Finally, in response to statement $6,46 \%$ of the teachers agree that students reflect on test performance and compare it with other students. On 
the other hand, $34 \%$ disagreed and only $20 \%$ found the statement not applicable. Results of responses related to implementing learner autonomy through teaching strategies are presented in Table 2.

TABLE 2.

TEACHERS' RESPONSES TO STATEMENTS RELATED IMPLEMENTING LEARNER AUTONOMY THROUGH TEACHING STRATEGIES

\begin{tabular}{|c|c|c|c|c|c|}
\hline Statements & $\begin{array}{l}5 \text { Strongly } \\
\text { Agree }\end{array}$ & 4 Agree & $\begin{array}{l}3 \text { Neither Or } \\
\text { N/A }\end{array}$ & 2 Disagree & $\begin{array}{l}1 \text { Strongly } \\
\text { Disagree }\end{array}$ \\
\hline $\begin{array}{l}\text { 1- Implementing learner autonomy in teaching through } \\
\text { communicative skills }\end{array}$ & $26 \%$ & $62 \%$ & $8 \%$ & $4 \%$ & 0 \\
\hline $\begin{array}{l}\text { 2- Group discussions are a good strategy to encourage } \\
\text { autonomous learning }\end{array}$ & $28 \%$ & $70 \%$ & $2 \%$ & 0 & 0 \\
\hline 3- Prefer learner-centered approach & $28 \%$ & $56 \%$ & $8 \%$ & $6 \%$ & 0 \\
\hline 4- Provide authentic learning materials & $28 \%$ & $56 \%$ & $8 \%$ & $8 \%$ & 0 \\
\hline $\begin{array}{l}\text { 5- Providing motivating environment to encourage learner } \\
\text { autonomy }\end{array}$ & $42 \%$ & $46 \%$ & $10 \%$ & $2 \%$ & 0 \\
\hline $\begin{array}{l}\text { 6- Students poor responsibility in learning affects the } \\
\text { implementation of learner autonomy }\end{array}$ & $38 \%$ & $34 \%$ & $16 \%$ & $8 \%$ & $4 \%$ \\
\hline
\end{tabular}

Results of the second category illustrated that $88 \%$ of the teachers encourage learner autonomy through communicative skills. Only $4 \%$ disagreed and $8 \%$ were not able to decide or found the statement not applicable. In response to statement 2 , a very high percentage of $98 \%$ of the teachers agreed that group discussions is a good strategy to encourage learner autonomy and only $2 \%$ found the statement not applicable. In teachers' responses to statement 3 , $86 \%$ of them prefer learner-centered approaches and believe that it helps in encouraging learner autonomy. Only $6 \%$ disagreed and $8 \%$ found statement 3 not applicable. A high percentage of $84 \%$ of the teacher's agreed with statement 4 and only $8 \%$ disagreed. Also, $8 \%$ found the statement not applicable or couldn't decide.

In response to statement $5,88 \%$ of the teachers' agreed to provide a motivating environment which encourages learner autonomy. Only $2 \%$ disagreed and $10 \%$ found the statement not applicable. Finally, $72 \%$ of the teachers agreed that the students' poor responsibility in learning affects the implementation of learner autonomy. Only $12 \%$ disagreed and $16 \%$ were not able to decide or found the statements not applicable. Results of responses related to the futuristic of learner autonomy are demonstrated in Table 3.

TABLE 3.

TEACHERS' RESPONSES TO STATEMENTS RELATED TO LEARNER AUTONOMY- FUTURISTIC

\begin{tabular}{|c|c|c|c|c|c|}
\hline Statements & $\begin{array}{l}5 \text { Strongly } \\
\text { Agree }\end{array}$ & 4 Agree & $\begin{array}{l}3 \text { Neither Or } \\
\text { N/A }\end{array}$ & 2 Disagree & $\begin{array}{l}\text { 1 Strongly } \\
\text { Disagree }\end{array}$ \\
\hline 1-Learners need continuous professional development & $42 \%$ & $46 \%$ & $10 \%$ & $2 \%$ & 0 \\
\hline 2- Reflection on teaching-learning process & $38 \%$ & $54 \%$ & $8 \%$ & 0 & 0 \\
\hline 3- Focus on learner training & $42 \%$ & $52 \%$ & $4 \%$ & $2 \%$ & 0 \\
\hline 4- Receive necessary support from the university & $52 \%$ & $42 \%$ & $4 \%$ & $2 \%$ & 0 \\
\hline 5- Learner should be as autonomous as possible & $52 \%$ & $38 \%$ & $10 \%$ & 0 & 0 \\
\hline 6- Learner training fosters reflective attitude & $54 \%$ & $36 \%$ & $8 \%$ & $2 \%$ & 0 \\
\hline
\end{tabular}

In the final category 'learner autonomy futuristic' results showed that $88 \%$ of the teachers believe that students need continuous professional development. However, only $2 \%$ disagreed and $10 \%$ responded with neither. In response to statement 2, $92 \%$ of the teachers agreed that reflection on teaching and learning processes helps promote learner autonomy in the future. Only $8 \%$ found the statement not applicable or couldn't decide. A high percentage of $94 \%$ of the teachers agreed with statement 3 and only $2 \%$ disagreed stating that focusing on learner training won't help with promoting learner autonomy and $4 \%$ responded with neither agreement nor disagreement.

Results of statement 4 revealed that $94 \%$ of the teachers agreed that university support is necessary to promote learner autonomy. On the other hand, only $2 \%$ disagreed and $4 \%$ were not able to decide and found the statement not applicable. Majority of the participated teachers (90\%), agreed with statement 5 in that learners should be as autonomous as possible and only $10 \%$ responded with neither. Finally, in response to statement $6,90 \%$ of the teachers agreed that learner training fosters reflective attitude. Only $8 \%$ responded with neither or found the statement not applicable. On the other hand, a low percentage of $2 \%$ disagreed with the statement. Results of the teachers' response analysis on encouraging learner autonomy are presented in Table 4.

TABLE 4.

RESULTS OF TEACHERS' RESPONSE ANALYSIS ON ENCOURAGING LEARNER AUTONOMY

\begin{tabular}{lll}
\hline \hline Category & No. of participants & $\%$ \\
\hline \hline (a) Student- centered instruction & 17 & $37 \%$ \\
\hline (b) Group work & 7 & $15 \%$ \\
\hline (c) Technology & 5 & $11 \%$ \\
\hline (d) Discussion & 3 & $6 \%$ \\
\hline (e) Homework & 8 & $17 \%$ \\
\hline (f) Skills & 3 & $7 \%$ \\
\hline (g) Other & 3 & $7 \%$ \\
\hline
\end{tabular}


Results of the first open-ended question as shown in table 4, revealed more about the teachers' in-class practices to promote learner autonomy. Majority of the teachers' comments indicate a strong encouragement of learner-centered approaches. A total of 17 (37\%) of English teachers mentioned the learner-centered approach as a strategy that helps promote learner autonomy Participant 2 stated "'I mostly use student centered instructions/activities as well as guided discovery". Participant no.13 agrees "Having a student-centered way of teaching that heavily relies on extracting information from students".

Another strategy teachers revealed in their comments was group work. A total of $7(15 \%)$ teachers believe that engaging students in group work helps promoting learner autonomy. Participant no.23 stated "By introducing group discussion, giving guidance and facilitating activities". Also, participant no. 32 agreed "I use mainly task based activities in small groups which fosters quite a bit of peer support and a lot of critical thinking. The students have to use the 4 skills and the activation of newly acquired vocabulary and grammar".

In reference to technology, $5(11 \%)$ participants stated that they use technology to help promote the concept. Participant no.46 stated "Using technology in the classroom helps a great deal. Also, allowing learners to do the tasks as role plays or a debate is helpful too". Only 3(6\%) of the teachers mentioned discussions as a classroom practice to encourage learner autonomy. Participant no.18 stated "Discussion is the most encouraging way".

Moreover, 8 participants mentioned homework in their comments and believed that asking students to complete a certain task at home or preparing a lesson helps encouraging LA. For example, participants no.37 stated "By encouraging them to prepare for the lesson before the lesson itself, by looking for the meaning of different vocabulary". However, only 3 teachers commented on using skills to encourage LA with a percentage of $7 \%$. Participant no.40 revealed "Mainly in writing portfolio by allowing students to write on their own first and then teaching the correct writing practice and discussing mistakes and how to correct them". Finally, 3 (7\%) teachers mentioned other comments related to classroom practices such as participant no.34 stating "I always try my level best to teach them according to it" and participant no.7 stating "In all ways. It's definitely for the benefits of both learner and teacher".

\section{F. Challenges Teachers' Face in Implementing Learner Autonomy}

For the second research question which was: What are the factors that may prevent teachers from encouraging and implementing learner autonomy in their classrooms? The results are presented in tables 5.

TABLE 5.

RESULTS OF RESPONSE ANALYSIS OF TEACHERS' COMMENTS ON IMPLEMENTING LEARNER-AUTONOMY STRATEGIES INTO THEIR EFL CLASSROOMS

\begin{tabular}{lll}
\hline \hline Category & No. of participants & $\%$ \\
\hline \hline (a) Time & 6 & $12 \%$ \\
\hline (b) Institution & 6 & $12 \%$ \\
\hline (c) Teachers' efforts & 5 & $10 \%$ \\
\hline (d) Learners' efforts & 7 & $14 \%$ \\
\hline (e) Students' level & 11 & $22 \%$ \\
\hline (f) Other & 15 & $30 \%$ \\
\hline
\end{tabular}

In reference to Table 5, the results illustrated that $6(12 \%)$ of the participated EFL teachers stated that time is an issue when trying to implement LA. For example, participant no. 2 stated "Yes. It's difficult due to the short time and the heavy material". Also, participant no.22 agreed "It is possible with extra time and some flexibility allowed".

In reference to the institution, $6(12 \%)$ of the teachers mentioned institution as a factor that may prevent them in implementing LA into their EFL classrooms. For example, participant no.7 stated "No, but certain EFL institutions do not encourage it or leave much room/time for it to be nurtured in a system that attempts to standardize the learning process".

Teachers' comments also revealed that only 5 of the participants believed that teachers' efforts can be a preventing factor if not existed. Participant no.16 stated "Where there is a will there is a way. Nothing is difficult if a clear strategy is implemented and applied in learning autonomy". On the other hand, 7 (14\%) teachers assert that the lack of students' effort can be a factor that prevents them from promoting LA. For example, participant no.41 stated "This depends on the type of student. If students are already motivated it would not be difficult but if students are weak and uninterested then it would be very difficult". Participant no.37 agreed stating "Not difficult but depends on the learners' willingness to take responsibility about her education (English learning)".

Results also showed that $11(22 \%)$ teachers believe that the student's level plays an important role in preventing LA. Participant no.26 stated "Yes, sometimes it depends on my learners' level of the English language". Participant no.49 agreed stating "If the learners are at or above level, it is possible". However, a total of 15(30\%) teachers responded with different comments that showed either a personal opinion of LA or to declare that they do not have an answer for the question such as participant no.43 commented "It is difficult when a class has a teacher-centered approach" another participant, no.42 stated "I don't know".

\section{DisCUSSION AND CONCLUSION}


Regarding teachers' Knowledge of learner autonomy, the results illustrated that EFL teachers are familiar with learner autonomy. However, when asked about the current situation, the majority of the teachers (42\%) disagreed with the statement that students in the current time are able to set up their own learning goals, only $28 \%$ of the teachers agreed with the statement. These results indicate that teachers believe that EFL Saudi learners lack basic necessary learner autonomy skills such as self-management, determining their learning goals and objectives. Teachers' negative feedback on the current situation is also revealed when asked about whether students tell them about what they would like to learn. A large number of teachers (44\%) disagreed with the statement. Only $36 \%$ of the teachers agreed that students are able to select and tell them what they want to learn. These results indicate that teachers assert Saudi learners are not able to determine their learning needs.

However, $58 \%$ of the teachers agreed that students are very concerned to perform well in the classroom and even a larger number of teachers $(64 \%)$ agreed that students think about their relationship to the rules they have learned while learning a new grammar rule. In contrast to the first two statements, teachers' agreement with statement 3 and 4 shows that students are aware of the importance of their role in the learning process even if they are unable to translate the awareness into actions such as selecting what they believe is important for them to learn. The high percentage of responses shows that students are concerned to perform well in class and to some extent monitoring their performance. Relatively as shown in statement 4 , most teachers believe that students try to rationalize and utilize what they have learned in the classroom. Most important statement related to the current situation of learner autonomy and teachers' perspectives, is statement no.5, teachers were asked if learners try to discover knowledge in English on their own rather than from the teacher. The majority of the teachers (42\%) disagreed with the statement stating that learners depend entirely on them (teachers) in discovering knowledge in English. Only 20\% agreed that their students are able to do so themselves.

In summary, the ELI teachers' perspective of the current situation of learner autonomy was generally negative. The majority of the participated teachers believe that students are not considered autonomous learners yet. On the other hand, some believed that students showed awareness of self-monitoring and concerns of in class performance, which indicates that students are taking some responsibility for their learning to some extent. However, teachers believe the Saudi language learners still lack learner-autonomy knowledge and skills. The results are in agreement with the findings of a research study conducted by Alrabai (2017) in King Khaled University, Saudi Arabia. The study aimed to examine Saudi learners' level of autonomy in language learning. The researcher clarified in his findings that by examining learners' capacity for independent learning and self-efforts in learning English, results revealed that Saudi learners were non-autonomous on both factors.

Results of the statements related to implementing learner autonomy through teaching strategies (see table.2), showed that a significant number of the ELI teachers have the knowledge to implement LA through particular teaching strategies that help encourage the concept. In a study conducted by Guilloteaux and Dornyei (2008), it is revealed that the students' performance and motivation is related to teachers' motivation and their classroom teaching strategies. The majority of the teachers agreed that communicative tasks are essential to promote learner-autonomy. Also, a large number of teachers agreed that group discussions, the learner-centered approach and providing authentic materials are all teaching strategies they use to promote LA. Relatively, $88 \%$ of the teachers believe that it is important to provide a motivating environment to help encourage LA. The results are in agreement with a research study conducted by Chen (2013) in South China University. The findings of the survey show that providing learners with the interactive environment such as using computer-assisted learning, which in this study was implemented using tablets, helps in promoting learner autonomy.

Despite the fact that majority of the ELI teachers showed satisfying knowledge of learner-autonomy, $72 \%$ of the participants believe that students' poor responsibility affects the implementation of learner autonomy.

In the final category, teachers were asked to respond to statements related to their perspective of Learner-autonomy futuristic. As mentioned before, the majority of English language teachers agreed that Saudi learners have poor learning responsibility. Similarly, in response to the first statement in the final category, results also revealed that $88 \%$ of the teachers believe that students need continuous professional development. Also, a higher percentage of $92 \%$ of the teachers agreed that reflection on teaching and learning processes helps promote learner autonomy in the future. The result is in line with a research study conducted by Reinders and White (2016) at Massey University, New Zealand. The researchers investigated the future of learner autonomy and found that literature in the field learner autonomy is in need of more focus on teachers' reflections to improve the teaching and learning processes. Furthermore, a high percentage of $94 \%$ of the teachers agreed that more focus on learner training in the future is also essential to help foster and promote the concept to Saudi learners. Teachers also reported in agreement that learner training fosters reflective attitude. The results are in agreement with the findings of Alrabai's (2017) research study; he revealed that the lack of learner training is a factor that contributed to ignoring learner autonomy in EFL Saudi setting.

In the fourth statement, participants' responses reported that $94 \%$ of the teachers agreed that university support is necessary to promote learner autonomy. This result is in agreement with the findings of an earlier research study conducted by Hooyeman, Wulf and Lewthwaite (2014) in the United States. In their conclusions, they indicated that autonomy-supportive conditions have multiple benefits for learning and encouraging learners to become more 
autonomous language learners. Also, majority of the participated teachers (90\%), agreed with statement 5 and that learners should be as autonomous as possible.

After completing the Likert-scale part of the questionnaire, teachers were asked to answer open-ended questions to elaborate and provide more explanation. The first open-ended question also aimed to reveal how much ELI English teachers know about learner autonomy in their own words. Also, teachers' comments showed information about in-class practices to promote learner-autonomy. The findings reported that a large number of teachers agreed that the learnercentered approach is a strong encouragement to learner autonomy. These results are in agreement with a research study that was conducted by Chen (2001), who found that language teachers should undertake more learner-centered activities when teaching EFL learners, by encouraging them to take more responsibility for their learning. Another strategy teachers revealed in their comments was group work. A total of $7(15 \%)$ teachers believe that engaging students in group work helps to promote learner autonomy. This is in agreement with a research study conducted by Ramos (2016) in Francisco University. In his study, he revealed that students should be provided with opportunities that enable them from being more independent learners. Hence, learning opportunities such as planning and working with others can help promote learner- autonomy.

Few teachers mentioned homework and completing tasks after class in their comments. Although the number of teachers who mentioned homework and after class tasks were small, the literature on learner autonomy revealed that most of the learning process takes place outside the classroom where learners are working alone. Reinders and White (2016) mentioned in their study that learner autonomy had a number of dimensions that includes a variety of settings in which learning can take place. Extra-curricular programs or out of class learning are all terms that refer to the location of where autonomous learning can take place. Another way to encourage learner autonomy emerged in the teachers' comments for focus on certain language skills such as concentrating on reading. The small number of teachers' comments shows that not all English teachers believe that focusing on certain language skills can benefit learner autonomy. All four language skills are the center of any English class. However, extra work on these skills and teaching learners to depend on themselves in developing them is a contribution to learner autonomy.

In conclusion, the majority of the participated teachers believed that Saudi English learners are not autonomous learners yet. Learner autonomy situation in Saudi Arabia lacks the need for students and teachers training, reflections on the teaching learning process and institutional support. This is how ELI English instructors perceived the future of learner autonomy and what is still needed to encourage such a concept in the Saudi setting. Also, teachers' comments reported some suggestion on learner autonomy encouragement that was also reported in earlier research studies. Hence, this indicates that majority of the participated teachers are familiar with learner autonomy teaching strategies. Although ELI teachers showed knowledge of learner autonomy yet, they still had a negative perspective of learner autonomy. The second research question investigates the factors that prevent teachers from applying those strategies.

Pertaining the factors that may prevent teachers from encouraging and implementing learner autonomy in their classrooms, results reported five factors that teachers believe affected their encouragement of learner- autonomy. These factors are time, institution, teachers' efforts, learners' efforts and students' level. The majority of ELI teachers believe that students' level is the strongest affecting factor that limits their implementation of learner autonomy. A higher number of teachers' (30\%) responded with comments that were not specific nor direct to the point. However, they presented their personal opinion suggesting that learner autonomy is difficult to incorporate into teaching Saudi learners. Others commented saying it is almost impossible (see comments table.7).

In conclusion, the findings reported that teachers have a negative perspective of learner autonomy in the current situation, stating that there are a number of reasons such as poor students' responsibility and not being able to determine what they need to learn. The findings also illustrated that there are a number of challenging factors that prevent the implementation of learner autonomy into Saudi EFL classrooms. Teachers mentioned in their comment answers number of factors such as time, institution, teachers' efforts, and learner efforts and students level. The majority of the teachers agreed that students' level is one of the main reasons why teachers find implementing learner autonomy in their teaching practice challenging. The findings show that Saudi learners are not autonomous learners yet. However, teachers agreed that both teachers and learners need professional training to help encourage learner autonomy in the future. Future education is moving towards autonomous learning. Therefore Saudi learners may need to be professionally trained. As the results show, teachers also lack professional training and develop learner autonomy knowledge.

\section{LIMITATION OF THE STUDY}

This research study may not be generalized to other countries but it could be generalized and applied to neighboring countries which have similar background and culture. It is also limited to female English teachers teaching in the foundation year. Accessing Male participants' data was difficult due to the laws and customs of Saudi Arabia therefore, this study was limited to female participants only.

\section{SUGGESTIONS FOR FURTHER RESEARCH}


Furthered research is advised to investigate other areas of learner autonomy on different samples such as male participants and varying levels of learners. A second suggestion is to study the role of the institution, environment and other possible elements that can provide valuable information on learner autonomy situation in Saudi Arabia. Finally, further studies on promoting and raising awareness of learner autonomy are highly encouraged.

\section{ACKNOWLEDGMENTS}

We would like to sincerely thank Mr. Abdulrahman Asiri for his continuous support and, the ELI research participants for their cooperation, without whom this research was not possible.

\section{APPENDIX}

Below are a number of statements regarding learner autonomy in language learning, also known as independent learning Please read each one and indicate to what extent you (as a language instructor) agree or disagree with each one. Please write your answer for questions 4 and 5.

1-Learner Autonomy - Current Situation

\begin{tabular}{|l|l|l|l|l|l|}
\hline Statements & $\begin{array}{l}5 \text { Strongly } \\
\text { Agree }\end{array}$ & 4 Agree & 3 Neither Or N/A & 2 Disagree & $\begin{array}{l}\text { 1 Strongly } \\
\text { Disagree }\end{array}$ \\
\hline a. Students set up their own learning goals & & & & & \\
\hline $\begin{array}{l}\text { b. The students tell the teacher what they would } \\
\text { like to learn }\end{array}$ & & & & & \\
\hline $\begin{array}{l}\text { c. Students feel very concerned to perform well } \\
\text { in the classroom }\end{array}$ & & & & & \\
\hline $\begin{array}{l}\text { d. Student think about their relationship to the } \\
\text { rules they have learned while learning a new } \\
\text { grammar rule }\end{array}$ & & & & & \\
\hline $\begin{array}{l}\text { e. Students try to discover knowledge in English } \\
\text { on their own rather than obtaining knowledge } \\
\text { from the teacher }\end{array}$ & & & & & \\
\hline $\begin{array}{l}\text { f. Students reflect on test performance and } \\
\text { compare it and compare it with other students }\end{array}$ & & & & & \\
\hline
\end{tabular}

2-Implementing Learner Autonomy through Teaching Strategies

\begin{tabular}{|l|l|l|l|l|}
\hline Statements & 5 Strongly Agree & 4 Agree & $\begin{array}{l}3 \text { Neither Or } \\
\text { N/A }\end{array}$ & 2 Disagree \\
\hline $\begin{array}{l}\text { a. Implementing learner autonomy in teaching } \\
\text { through communicative skills }\end{array}$ & & & & \\
\hline $\begin{array}{l}\text { b. Group discussions are a good strategy to } \\
\text { encourage autonomous learning }\end{array}$ & & & & \\
\hline $\begin{array}{l}\text { c. Prefer learner-centered approach } \\
\text { d. Provide authentic learning materials }\end{array}$ & & & & \\
\hline $\begin{array}{l}\text { e. Providing motivating environment to encourage } \\
\text { learner autonomy }\end{array}$ & & & & \\
\hline $\begin{array}{l}\text { f. Having poor teaching facilities affect the } \\
\text { application and encouragement of learner } \\
\text { autonomy }\end{array}$ & & & & \\
\hline
\end{tabular}

3-Learner Autonomy - Futuristic

\begin{tabular}{|l|l|l|l|l|}
\hline Statements & $\begin{array}{l}\text { 5 Strongly } \\
\text { Agree }\end{array}$ & 4 Agree & 3 Neither Or N/A & 2 Disagree \\
\hline a. Learners need continuous professional development & & & & \\
\hline b. Reflection on teaching-learning process & & & & \\
\hline c. Focus on learner training & & & & \\
\hline d. Receive necessary support from the University & & & & \\
\hline e. Learner should be as autonomous as possible & & & & \\
\hline f. Learner training fosters reflective attitude & & & & \\
\hline
\end{tabular}

4-In what way are you encouraging learner autonomy in the classroom?

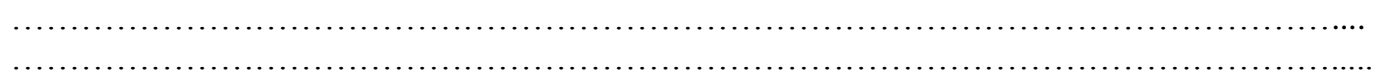

5-Do you think it is difficult to implement learner autonomy strategies in EFL classrooms? 


\section{REFERENCES}

[1] Al Asmari, A. (2013). Practices and Prospects of Learner Autonomy: Teachers' Perceptions. English Language Teaching, 6(3), $1-10$.

[2] Alrabai, F. (2017). Exploring the Unknown. The Autonomy of Saudi EFL Learners, English Language Teaching: Canadian Center of Science and Education, 10(5), 226-227.

[3] Al-Shaqsi, T. S. (2009). Teachers' beliefs about learner autonomy. In S. Borg (Ed.), Researching English language teaching and teacher development in Oman (pp. 157-165). Muscat: Ministry of Education, Oman.

[4] Benson, P. (2013). Teaching and researching: Autonomy in language learning. New York: Routledge.

[5] Benson, P., \& Voller, P. (2014). Autonomy and independence in language learning. New York: Routledge.

[6] Borg, S., \& Al-Busaidi, S. (2012). Learner autonomy: English language teachers' beliefs and practices: ELT Journal, 12(7), 145.

[7] Burkert, A. \& Schwienhorst, K. (2008). Focus on the student teacher: The European portfolio for student teachers of Languages (EPOSTL) as a tool to develop teacher autonomy. International Journal of Innovation in Language Learning and Teaching, 2(3), 238-252.

[8] Camilleri, G. (1999). Learner autonomy: The teachers' views. Retrieved november14, 2017 from http://archive.ecml.at/documents/pubCamilleriG_E.pdf.

[9] Candy. (1991). Self-direction for Lifelong Learning. California: Jossey-Bass.

[10] Chan, V. (2001). Readiness for learner autonomy: What do our learners tell us?: Teaching in higher education, 6(4), 505-518.

[11] Chen, X. B., \& Kessler, G. (2013). Action research tablets for informal language learning: Student usage and attitudes: Language Learning \& Technology, 17 (1), 28-29

[12] Dang, T. T. (2010). Learner Autonomy in EFL studies in Vietnam: A discussion from a sociocultural perspective. English Language Teaching: Canadian Center of Science and Education, 3(2), 5-4.

[13] Guilloteaux, M. J., \& Dörnyei, Z. (2008). Motivating language learners: A classroom-oriented investigation of the effects of motivational strategies on student motivation: TESOL quarterly, 42(1), 72-73.

[14] Hancock, B., Ockleford, E., \& Windridge, K. (1998). An introduction to qualitative research. Nottingham: Trent focus group.

[15] Ho, J., \& Crookall, D. (1995). Breaking with Chinese cultural traditions: learner autonomy in English language teaching: Pergamon, 2(23), 236-237.

[16] Holec, H. (1979). Autonomy and foreign language learning. Strasbourg: Council of Europe.

[17] Holec. (1981). Autonomy and foreign language learning. Strasbourg: Council for Cultural Cooperation.

[18] Hooyman, A., Wulf, G., \& Lewthwaite, R. (2014). Impacts of autonomy-supportive versus controlling instructional language on motor learning: Human Movement Science, 36, 190-198.

[19] Johnson, B., \& Turner, L. A. (2003). Data collection strategies in mixed methods research. Handbook of mixed methods in social and behavioral research. California: Sage Publications

[20] Khan, I.A. (2011). Learning difficulties in English: Diagnosis and pedagogy in Saudi Arabia. Educational Research, 2(7), 1252-1251

[21] Kongchan, C., \& Darasawang, P. (2015). Roles of Self-Access Centres in the Success of Language Learning. In Innovation in Language Learning and Teaching. UK: Palgrave Macmillan.

[22] La Ganza, W. (2008). Learner autonomy-teacher autonomy. Learner and teacher autonomy: Concepts, realities and responses. Amsterdam: John Benjamins Publishing.

[23] Little, D. (1995). Learning as dialogue: The dependence of learner autonomy on teacher autonomy. System 23 (2), $175-181$.

[24] Little, D. (2000). Learner autonomy: Why foreign languages should occupy a central role in the curriculum. In S. Green (Ed). Lew perspectives on teaching and learning modern languages, 24-45. Frankfurt Lodge: Cromwell Press Ltd.

[25] Little, D., \& Dam, L. (1998). Learner autonomy: What and why?: Language Teacher- Kyoto,22(1),9-10

[26] Ramos, R. C. (2016). Considerations on the role of teacher autonomy. Colombian Applied Linguistics Journal, (8), $183-202$.

[27] Reinders, H. (2014). Personal Learning Environments for Supporting Out-of-Class Language Learning: English Teaching Forum. 52(4), 14-15

[28] Reinders, H., \& White, C. (2016). 20 years of autonomy and technology. How far have we come and where to next?: Language Learning \& Technology, 20(2) 147-148.

[29] Schmenk, B. (2005). Globalizing learner autonomy: TESOL Quarterly, 39(1), 107-118.

[30] Smith, R. C. (2008). Learner autonomy (Key concepts in ELT). ELT Journal, 62 (4), 395-397.

Jamilah Aseeri is presently an MA candidate in the TESOL program, English Language Institute, King Abdulaziz University, Saudi Arabia. She has completed her Bachelors's degree in Applied Linguistics and Translation. She has taught English in Yanbu University College, Effat University, and is currently employed in the Jeddah International College. Her research interests are Second Language Acquisition, Second Language Learning and Language Teaching and Learning.

Nadia Shukri has a Doctorate of Education (TESOL) from the Leicester University, United Kingdom. She is an Associate Professor (Applied Linguistics:TESOL) in the English Language Institute, King Abdulaziz University, Saudi Arabia. She is currently teaching and supervising graduate students in the Master/TESOL program. Her research interests include Teacher Education, Second Language Writing, and Blended Learning. 